\title{
"Green Urban Transport" Modes and Arrangements: A Case Study on Authorities and Responsibilities of Local Governments in Turkey
}

\author{
Hulagu Kaplan \\ Gazi University, Ankara, Turkey \\ Zümrüt Özbahar (Kaynak) \\ The Ministry of Environment and Urbanization, Ankara, Turkey
}

\begin{abstract}
Because of the irregularities in the flow of urban road traffic emissions, noise and visual pollution, climate change, and energy efficiency policies; transportation issues continue to be an important issue at the environmental level. Even guidelines for urban transport have been specified by framework laws, regulations, strategic documents, and action plans, the implementation of the decisions is already faced with difficulties. Partitive and vehicle-oriented approaches cause a raise in copy-paste method in urban transportation implementations. The purpose of this paper is to examine the responsibilities of the central and local governments in the scope of the energy efficiency of urban transportation, environment and climate sensitivity measures. For this purpose, paper will, respectively: (1) focus on the reasons which justify reasons of green urban transportation in accordance with international resolutions and documents since 1970; (2) inform about legal and administrative decisions for environmentally-sensitive and energy-efficient urban transportation implementations; and (3) carry out an assessment of measures to improve the energy efficiency of urban transportation and environmental sensitivity within the framework of time-cost-plan-policy packages.

Keywords: sustainable urban transport policy, green-clean transportation, energy efficiency, environmental problems of transport, local government
\end{abstract}

The rapid development in technology and industry since 1990's has led to the rapid depletion of energy sources, and in particular, fossil-derived energy sources. Because of the global energy crisis, energy shortages particularly at fossil fuel based energy sources have led to new searches towards clean and renewable energy sources. The tendency of clean and renewable energy sources has also led to the expansion of these energy sources' application areas. At this stage, both the industry and the transport sector as an important component

Hulagu Kaplan, Ph.D., professor, Department of City and Regional Planning, Gazi University, Ankara, Turkey; research fields: urban planning (general and tourism), urban design, sustainable planning, sustainable transportation and urban transportation planning, energy efficiency/conservation-urban form relations, ecological urban design, accessibility planning and design.

Corresponding author: Zümrüt Özbahar (Kaynak), Ph.D. student, master degree on Traffic Planning and Implemention, bachelor degree (BhD) on Urban and Rural Planning, urban planner, traffic planning expert, The Ministry of Environment and Urbanization, Ankara, Turkey; research fields: energy efficient urban transportation planning, climate change and environmental issues and sustainability in both urban planning and urban transport, central and local authorities' responsibilities in terms of urban transport issues. 
of the service sector have become a decisive factor for renewable and clean energy production and consumption.

Land-use format, especially road transportation deteriorates soil quality noticeably. Exhaust gases arising from motor vehicle as an important factor in the formation of air pollution are among the factors that profoundly affect the relationship between transport and environment. The intensification of the increase in road traffic creates the noise pollution. The lack of suitable locations for the use of pedestrians and bicycles has also a negative impact on the general character of the environment.

Conservation of the environment, sustainability, energy sources, reduction of greenhouse gas emissions that occur during the production and consumption, climate change, and energy efficiency issues caused to take such measure called "green transport" ensuring the sustainability of urban transport at global, national, and local level.

At this stage, it would be useful to take a look briefly to the decisions that support "green transport" in urban transportation at international decisions.

\section{Energy Efficiency Measures of Urban Transport}

Approximately 24 million motor vehicles are in traffic in the world each year. Number of motor vehicles is 751 million in the world as of 2000. The number of vehicles per 1,000 population is 465 in the European Union (EU) member countries (Kaynak \& Kaplan, 2009).

With rapidly growing number of motor vehicles and the length of highways, noise and air pollution caused by roads, and fossil fuel energy sources' and their derivatives' usage by motor vehicles, their negative effects on global emissions are some of the reasons to make a re-evaluation on the transportation type and functions. The other reasons are the negative impact of road transportation on human health, negative effects of road transport on accessibility that is a need to incerase the quality of life, and the participation role of citizens to all sectors of urban functions.

Road transport accounts for $80 \%$ of total energy demand in Europe (Grazi \& van den Bergh, 2008). In 2020, the EU Energy and Climate Package aims to reduce all greenhouse gas emissions by $20 \%$ (McGlade, 2008). The $53 \%$ of worldwide transportation is for road to transport passengers, road transportation is responsible for $23 \%$ of global $\mathrm{CO}_{2}$ emissions, and $13 \%$ of greenhouse gas emissions. Emissions arising from passenger and freight transport in road transportation correspond to $2 / 3$ of all transport emissions. According to the OECD/ITF 2008 data, $\mathrm{CO}_{2}$ emissions are expected to increase by $120 \%$ due to land transport in 2050 compared to 2000 (Gust \& Expert Commission on Cities and Climate Change, 2010).

Because of all such reasons and data, such modern approaches like "speed", "uninterrupted flow of motor vehicles", and "vehicle-oriented" are replaced with post modern approaches as if "human-oriented", "spatial-environmental quality", and "street livability" (Kaplan, 2011). For energy-efficient and low-carbon mobility, travel and transport needs and methods have been preferred to reduce the use of fossil fuels. These methods are grouped under the heading of "clean energy". In this context, under the name of the urban development, the "integrated green community", "eco-cities", "green city", "carbon zero cities", and "smart cities" including "green routes (greenways)" have been created as an important policy in urban planning and integrated transport. Public transport systems and non-motorized transport infrastructure are tried to be developed with "clean energy and clean transport" innovations. These methods and procedures are discussed here under the heading of "green transportation". 
At this stage, it is useful to take a look at the current international instruments and desicions that support the emergence of "green transport" and "energy efficient urban transportation" concerns.

Within the framework of sustainability, perhaps the first relationship between transport and environment is linked with Cardiff Summit. The process starting with this summit envisaged the integration of environmental protection to all related activities (Kaplan, 2011).

By 2002 Transport White Document, the implementation of an integrated transport system is envisaged for a period of 15 minutes with an average walking distance $1.5 \mathrm{~km}$ and $3.5 \mathrm{~km}$ long with a bicycle taking into account the daily amount of human physical activity (Kaplan, 2011).

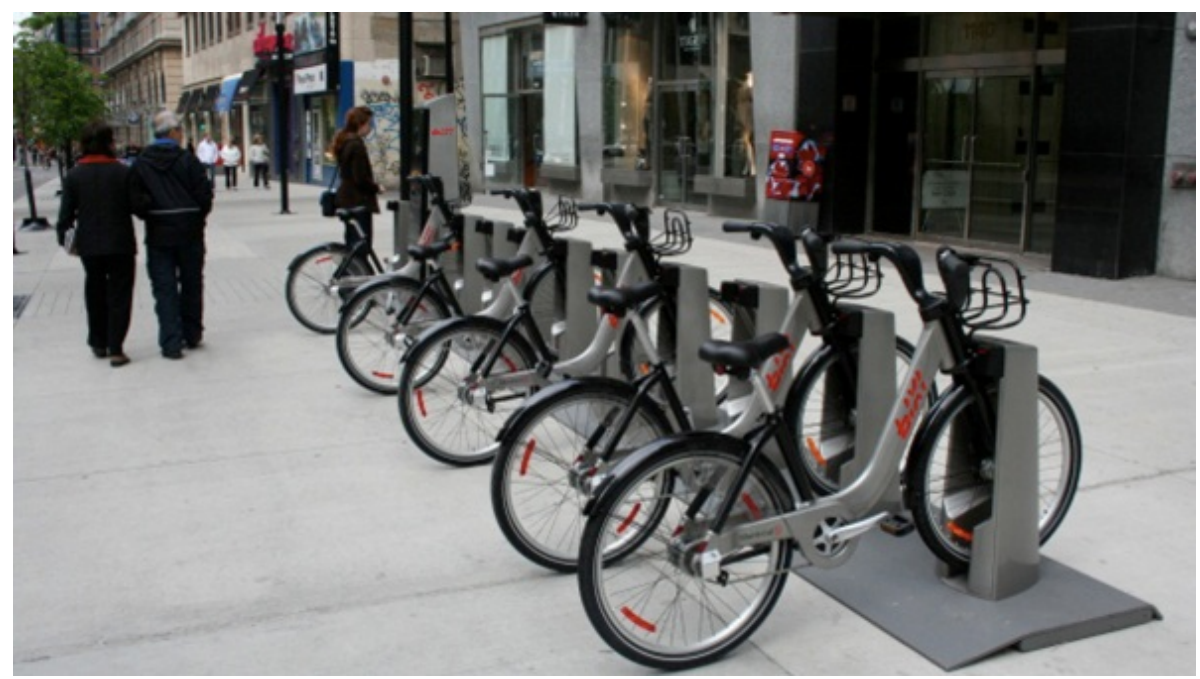

Figure 1. Cycling as a type of eco-friendly transport.

Urban Charter of Stockholm, which was published in 2004 by the Council of the Europe, is an important document emphasizing the importance of co-ordination and integration of transport and the Charter focuses on pedestrian movement and also public transport (Kaplan, 2011).

Direct and indirect measures are classified in order to reduce $\mathrm{CO}_{2}$ emissions derived from the transport sector according to the target group in Table 1. According to the table, spatial organization measures are classified as indirect measures. The measures envisaged in the long term are urban road investments, re-planning of settlements and offices, re-arrangement of parking spaces, and the use of existing buildings.

According to the table, the road pricing measures, regional charges, the parking charges, speed limits, and vehicle restrictions are the measures which could be developed in the short term under the Traffic Target Group. It would be useful to draw attention to here that these measures can easily be applied by local authorities.

On the other hand, land-use strategies influencing the choice of trip are grouped as (McGlade, 2008):

(1) Improvement of local service for access by foot or bicycle and the improvement of public transport provisions;

(2) Diversity of local services and employment opportunities to create mixed-use;

(3) Density along transportation corridors;

(4) Ensure the accessibility of public transport in regions with high urban development;

(5) Reduce the number of parking spaces;

(6) Handling public transportation systems as a part of planning system; 
(7) Implementation of park-and-ride systems;

(8) Setting up journey scenarios and taking measures according to these scenarios.

Factors such as: wasted energy, land management, water and air quality, and noise and visual pollution, and physiological and psychological effects of these factors on users led to a change in transport types and arrangements, under the name of "green urban transportation".

Table 1

The Role of Transportation in Context of Climate Change (Grazi \& van den Bergh, 2008)

\begin{tabular}{|c|c|c|c|c|}
\hline \multirow{2}{*}{ Target } & \multicolumn{2}{|l|}{ Sunday-Based tools } & \multicolumn{2}{|l|}{ Management and control measures } \\
\hline & Direct & Indirect & Direct & Indirect \\
\hline Vehicle & \begin{tabular}{|l|} 
Emissions per \\
vehicle taxes $(\mathrm{O})$ \\
\end{tabular} & \begin{tabular}{|l|} 
Vehicle taxes \\
differentiation $(\mathrm{K})$ \\
\end{tabular} & Emission standards (O) & $\begin{array}{l}\text { Obligation to use the less } \\
\text { polluted vehicles }(\mathrm{O})\end{array}$ \\
\hline Fuel & thes & $\begin{array}{l}\text { Different fuel taxes }(K) \\
\text { High fuel taxes }(K)\end{array}$ & $\begin{array}{l}\text { Chemical composition of fuels } \\
\text { (U) } \\
\text { Removal of high polluting fuels } \\
\text { (U) }\end{array}$ & $\begin{array}{l}\text { Fiscal-Monetary incentives for } \\
\text { replacing old vehicles (U) }\end{array}$ \\
\hline Traffic & $\begin{array}{l}\text { Road pricing }(\mathrm{K}) \\
\text { Emissions charges } \\
\text { per kilometer }(\mathrm{K}) \\
\end{array}$ & $\begin{array}{l}\text { Regional charges }(\mathrm{K}) \\
\text { Parking charges }(\mathrm{K})\end{array}$ & Traffic restrictions $(\mathrm{O})$ & $\begin{array}{l}\text { Speed limits }(\mathrm{K}) \\
\text { Restrictions on the use of motor } \\
\text { vehicles }(\mathrm{K})\end{array}$ \\
\hline Infrastructure & - & - & $\begin{array}{l}\text { To capture emissions } \\
\text { underground transport (U) }\end{array}$ & $\begin{array}{l}\text { Field capacity constraints }(\mathrm{K}) \\
\text { Urban rail transportation }(\mathrm{O})\end{array}$ \\
\hline $\begin{array}{l}\text { Spatial } \\
\text { organization }\end{array}$ & - & Land taxation (U) & 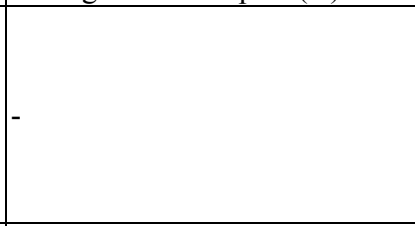 & $\begin{array}{l}\text { Urban road investments (U) } \\
\text { Re-planning of settlements and } \\
\text { offices }(\mathrm{U}) \\
\text { Regulation of parking places (U) } \\
\text { Change in use of existing } \\
\text { buildings functions (U) }\end{array}$ \\
\hline Information & $\begin{array}{l}\text { Research and } \\
\text { development } \\
\text { activities in the } \\
\text { subsidy (U) } \\
\text { Patent legislation (U) } \\
\end{array}$ & - & - & $\begin{array}{l}\text { Public awareness and education } \\
(\mathrm{O}) \\
\text { Public private sector investment } \\
\text { in R\&D (U) }\end{array}$ \\
\hline
\end{tabular}

Note. U: Long term, O: Medium term, K: Short term.

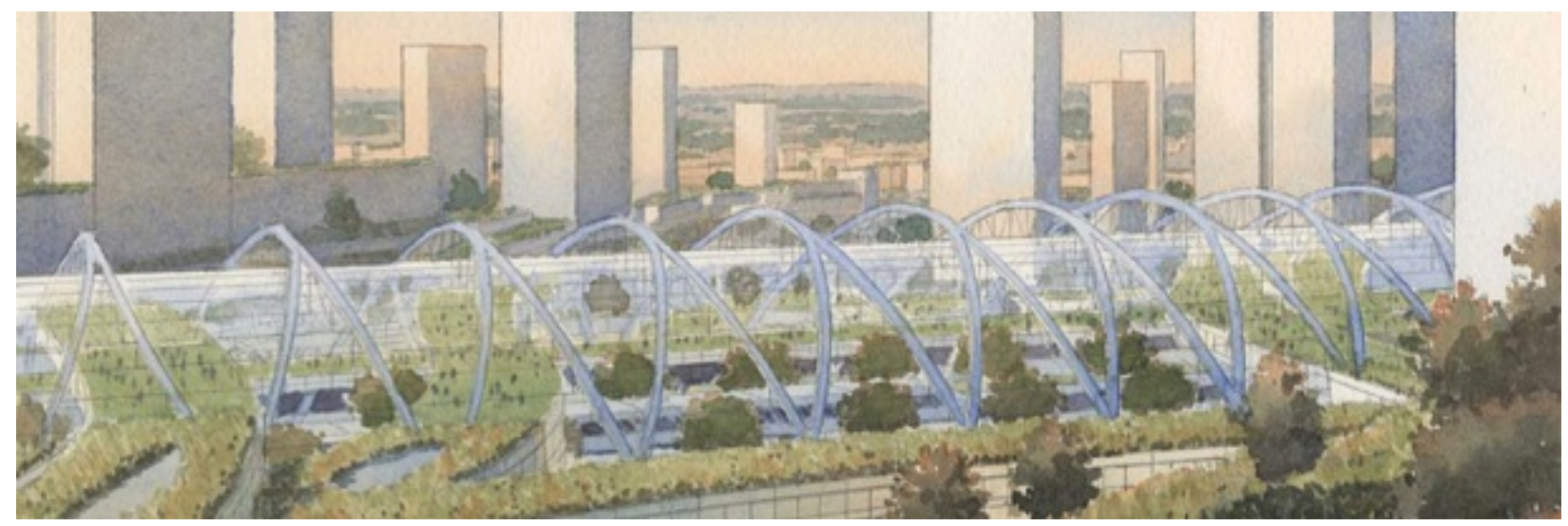

Figure 2. Transport line of Langfang eco-city.

As one unit increase in railway transportation causes 2,203 times positive effect on other sectors, the development of decisions and policies on railways has been accelerated in the world wide because of its positive effects on cost efficiency, energy consumption, environment, accessibility, and land use issues (Kaynak \& Kaplan, 2009). Considering that possitive effect, such ecologically and environmentally sensitive, 
friendly, and resilient transport solutions are being into implementation worldwide (see Figures 1, 2, and 4) (Kaplan \& Kaynak, 2011).

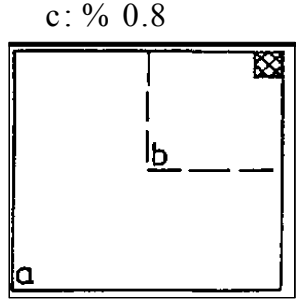

1

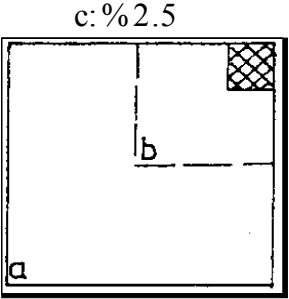

2

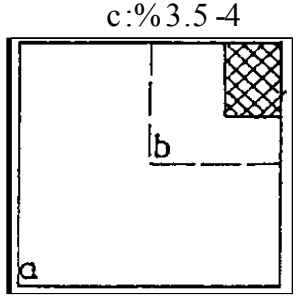

3 $\mathrm{c}: \% 15 \mathrm{~d}: \% 55$

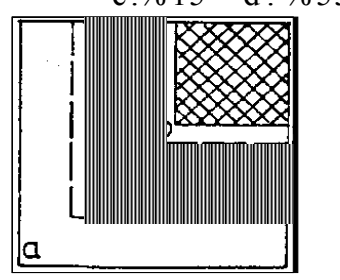

4

Figure 3. Schematic presentation of different user types' area requirement (Kaplan, 1996).

Notes. 1: (heavy and light rail), 2: (private otobus or tramway), 3: (trolleybus, otobus), 4: (automobile); a: 100\% urban space, b: $20 \%$ central business district space, c: Percentage of the related transportation mode which is needed, d: Parking space (schematic presentation). Urban Rail Systems (URS) include: tramway, light rail systems (LRS), and Heavy Rail Systems (HRS = Metro).

The figure above (see Figure 3) illustrates the impact of transport on greenhouse gas emissions. That figure makes easier the understanding of the relationship between the urban surface and the usage of transportation modes. According to Figure 3, when the surface of the city center is about $20 \%$, the need for road surface is $15 \%$ with passenger vehicles, the parking surface requirement is $55 \%$ of the total area and this ratio could be raised up to $70 \%$ (Kaplan, 1996).

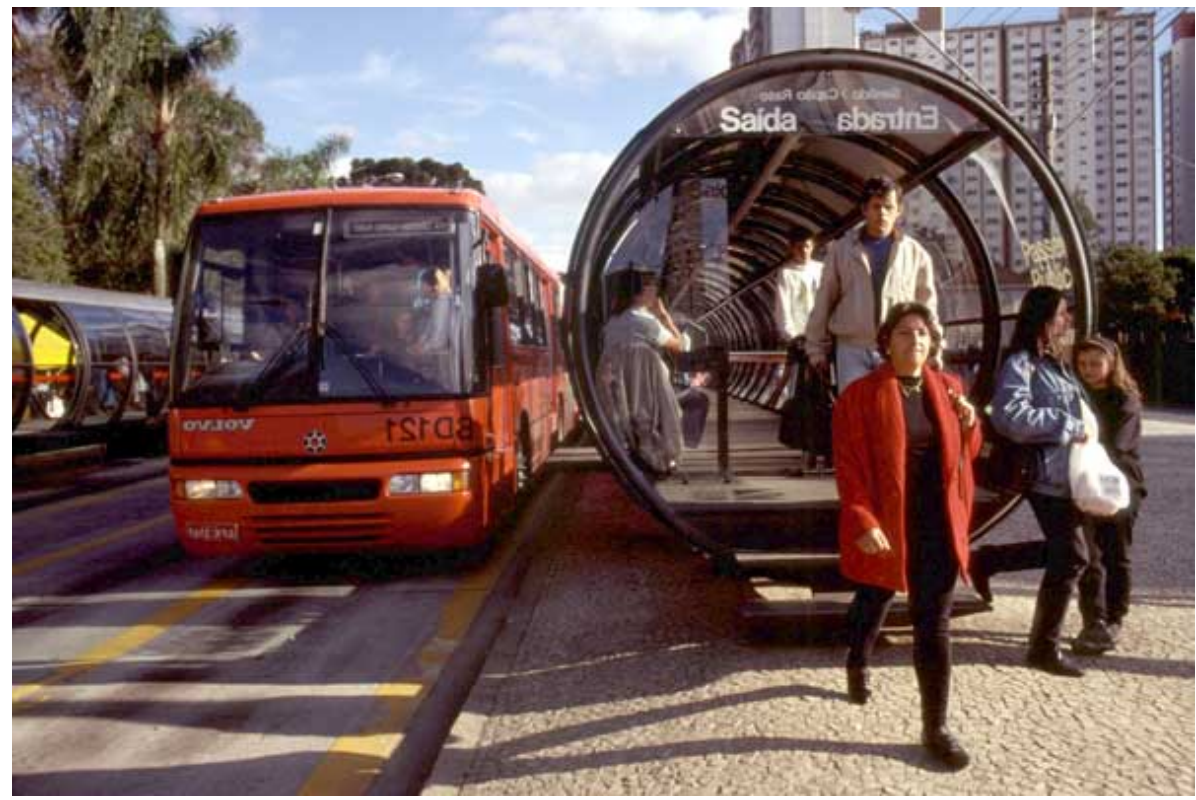

Figure 4. An eco-vehicle bus, Kuritiba city.

Providing the growing demand of new road capacity space is both valuable and limited in metropolitan cities. Each application of any new road capacity expansion gives rise to new demand which is not calculated before, therefore, supply-demand balance could not be fixed by this way and contruction of new roads brings to the emission increase and natural environmental damages that cause noise pollution. And all those reasons also lead to increased transportation problems exponentially. The approach adopted for the solution of traffic 
problems in the past was usually in the form of seeking solutions of traffic congestion. The traffic jam problem is tried to be overcome with the measures of enhancing the capacity of road. The following figure (see Figure 5) shows the difference between the traditional approach and contemporary approach.
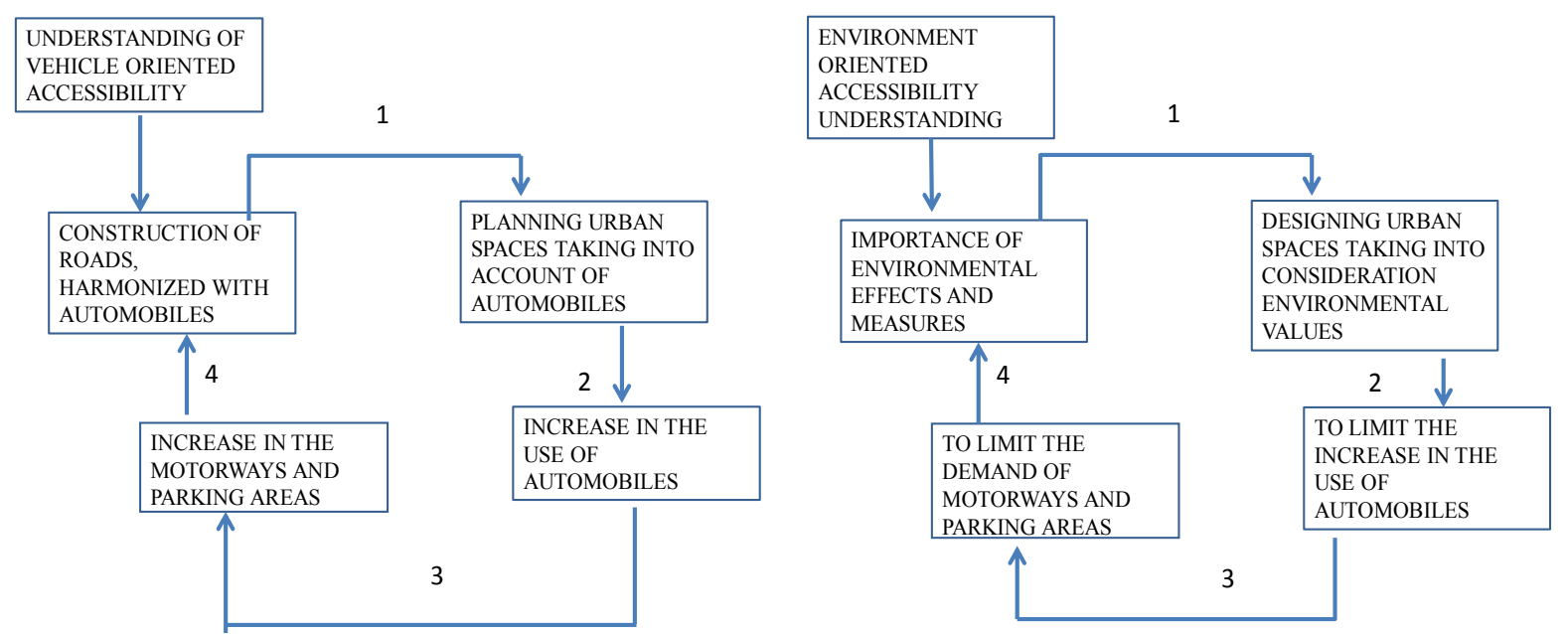

Figure 5. Urban transportation regulations under the energy efficiency at central and local level.

According to the data of "The EU Integrated Environmental Approximation Strategy-UÇES/NEAP of Turkey, 2006", there has been a significant increase in emissions of harmful exhaust gases because of the increase in the number of motor vehicles in recent years.

In Turkey, 93\% of passenger and freight transport is carried out by road vehicles, $93 \%$ of fuel used for transportation is oil derivatives. According to data from the Ministry of Transport, $25 \%$ of national greenhouse gas emissions is due to transport sector. In Turkey, the number of vehicles per 1,000 population is around about 145 and a total of $61,000 \mathrm{~km}$ highway exists by the year $2004^{1}$.

The transportation vision of Turkey (Ministry of Transport, 2005) is defined as:

Not compromising the rights and welfare, providing the life safety as one hundred percent, compatible with the rules of international law and the contemporary technology in a situation that environment is protected at the highest level, travel time is up to 1.5 hours between cities and urban transport is in 30 minutes (this period is twice the freight transport) provided.

Turkey's National Programme's ${ }^{2}$ objectives are stated as:

The existing administrative, legal and technical infrastructure will be re-established for the preparation of development plans in line with transportation master plans, instead of speed motorways and interchange chain-storey intersections, rail systems, pedestrian and bicycle paths are aimed to be provided with financial assistance to these regulations.

To address the usage of energy in the most efficient and economical way each stage, at that plan, following topics are emphasized:

(1) The preparation of a comprehensive national urban transport strategy guiding the private sector sustainable and consistent with energy, environment, economy, housing, and land policies;

\footnotetext{
${ }^{1}$ Ministry of Transport. Retrieved from http://www.ubak.gov.tr/BLSM_WIYS/.../20110408_092927_204_1_44520.pps.

2 Turkey's National Program. (2004). Retrieved from http://netbul.com/superstar/ozeldosyalar/siyaset/Avrupa_birli1i/ulusal.asp.
} 
(2) The preparation of an urban transport planning based on the provision of pedestrian movement which is environmentally sound, economically efficient, participatory, secure, and sustainable, taking care of the use of local resources to minimize dependency and offer equal opportunities to all segments of society;

(3) Making an assessment of land-use decision and its effects on transportaion at each scale, providing diversity and integration of urban transport modes according to the city's unique structure, dynamics, and potentials;

(4) Giving priority to public transport and pedestrian and bicycle transportation to market to establish a sustainable urban transport system in the process of EU integration;

(5) Making necessary arrangements at the bodies which have the responsibilities at the urban transportation decision making, policy implementation, and audit stages at the national and loca level.

"Medium-Term Programme" ${ }^{3}$ also mentions "Energy and Transport Infrastructure Development" to increase the support within the framework of the Energy Efficiency Act.

Vision 2023 Technology Foresight Project (TUBITAK, 2004) emphasizes the importantance of transportation as an indicator in determining the level of development of countries and the need of the transport sector planning. In this project, economy, speed, safety, and comfort ranked as the characteristics of transportation system. According to project report, least polluting and the ones using the existing energy resources minimize the energy consumption. And maintainability should be favored in the choice of transport modes.

Energy Efficiency Strategy Document ${ }^{4}$ (2012-2023) of Turkey also aims at energy reduction in the transportation sector.

Such actions are envisaged in the "Turkey Industry Strategy Document" to prevent unnecessary fuel consumption and for the reduction of the the consumption of fossil fuels of motor vehicles to increase the share of public transport at land, sea, and rail routes and urban transportation. These actions are:

(1) The preparation of transportation master plans to enforce transportation systems, bicycle and car parking areas primarily in the light of the public transportation in metropolitan cities;

(2) The reduction of the share of road transport to develop sufficient alternative modes of transport, increasing the share of railways and sea transport for freight and passenger transport;

(3) The increase in the implementation of intelligent traffic management practices by using information and communication technologies and intelligent transport systems for the provision of energy efficiency and the efficiency of public transport network.

At Turkey's National Climate Change Strategy Document ${ }^{6}$, there are strategies on urban transportation to decrease the GHG emissions.

The purpose of "Assessment and Management of Environmental Noise Regulation" (The Ministry of Environment and Urbanization, 2010) is to provide necessary measures to be taken to avoid damage to the physical and mental health composed by the environmental noise, for the people's rest and peace. The strategic noise maps must be prepared in accordance with the regulations. Depending on the noise maps, to reduce noice pollution, prevention measures consist of:

(1) Measures on city planning;

(2) Measures for Traffic planning and preparation;

\footnotetext{
3 2011-2013 Medium-Term Program. Published in the Official Gazette, dated October 10, 2010.

4 2012-2023 National Energy Efficiency Strategy Paper. Published in the Official Gazette, dated February 25, 2012.

5 Turkey's Industrial Strategy Document. Retrieved from http://www.sanayi.gov.tr.

${ }^{6}$ National Climate Change Strategy 2010-2020. Retrieved from http://www.csb.gov.tr.
} 
(3) Structural measures to reduce audio distribution (roads and buildings technical measures to be taken in roads and buildings);

(4) Measures to encourage public transport (extension of public transport network, submission of comfortable and fast service);

(5) Measures on public relations and the public information system.

According to the Energy Efficiency Law No. 5627 dated April 18, 2007, "Regulation on the Principles and Procedures for Promotion of Energy Efficiency in Transportation" has been published. Regulation aims at the reduction of fuel consumption, raising efficiency standards for vehicles, dissemination of public transport, and the establishment of systems to improve traffic flow. The Ministry of Interior Affairs is responsible for taking the measures to reduce the use of motor vehicles in urban centers and construction of parking lots. Both Ministry of Transport and the Ministry of Interior Affairs are responsible for taking the measures about direction signs, electronic route guidance system, travel demand management, traffic management, interspecific transport, urban transport planning, public transport, fuel consumption monitoring, and traffic signaling systems.

According to the regulation, transport efficiency, productivity, and convenience for drivers, travel demand management, interspecific transport system, traffic management, road direction signs, and electronic guidance systems will be implemented by relevant institutions/organizations. Instead of entering the high-traffic areas, alternative routes and modes will be provided for the trafic improvement. Central computer system will be established by municipalities with the population of over 250,000. Municipalities are also responsible for doing settlement plans and urban renewal projects and the establishment of parking for motor vehicles at the entrance of the city, reduction of the use of motor vehicles in urban centers, and performing public transport stops and stations for the generation of the transport system.

"Urban transport plan" is defined by the regulation and it is stated that:

Allowing the sustainable development and spatial, demographic, topographic, functional, social, economic characteristics of the city, transport demand is kept to a minimum level. Transportation plans will be prepared in coordination with the upper and lower scale plans, as well as traffic management, travel demand management, intermodal transport system, signaling systems and the green wave system are taken into consideration.

According to the regulation, municipalities are responsible for:

(1) The establishment of parking areas at the entrance to the city in site plans and urban renewal projects for motor vehicles;

(2) The implementation of rules to reduce the use of vehicles at the city center enabling the access to urban centers;

(3) Giving priority to the establishment of intermodal transport system at vehicle public transport stops and stations.

According to the regulation, metropolitan municipalities and other municipalities with the population of over hundred thousand inhabitants have the responsibility for preparing transportation master plan. City plans for sustainable urban transport planing should be prepared considering the urban plans in accordance with the urban transport plans within three years of the date of publication of the regulation.

Considering that the local authorities have the responsibility of sustainable urban transport plans, at all the settlement plans, transpostation studies should be done according to the Regulation on the Principles of the Construction of the Plan of the Law number 3194. 
Preparation of transportation planning is also addressed at the Technical Contract of the Bank of Provinces $^{7}$ emphasizing the issues of the estimated demand for transport transportation system, transportation network, standard and capacities, pedestrianization, geometric arrangements, and traffic management.

Metropolitan Municipality Law No. 5216 has rules and obligatory statements on metropolitan transportation planing and implementation, public transport services, number of public transport and taxis, ticket fees and tariffs, time and routes determinations, bus stops, car parks, and all other transport issues.

Evaluation Reports of Environmental Problems and Priorities Inventory in Turkey are prepared periodically for each two years, the first report is prepared including the years of 1999-2000 and the final report was published in 2014. Each report consists of the two years' period before it is published. Over the time, criteria of environmental problems and priorities taken into consideration in the report have been developed.

In this study, data are compared with each other, for the last four reports. These data are indicators of air and noise pollution, and a framework has been drawn for the provinces which are sorted according to these criteria.

According to the Evaluation Report of Environmental Problems and Priorities Inventory in Turkey ${ }^{8}$, traffic is ranked as first among the sources of air pollution in three cities at the 2008 report, in two cities at the 2010 report, in four cities at the 2012 report, and in five cities at the last report.

Among the measures taken for the aim of air pollution prevention, motor vehicle exhaust gas measurements are discussed as a method of precaution in 75 provinces at the 2008 report and it is the measure in the second-highest ranking emerging as a striking case. However, motor vehicle exhaust gas measurements are not taken into account at the 2010 report. As to 2012 report, it is at the 3 th rank and to the last report, it is at the 2nd rank.

When the same report is examined, urban transport is stated as a reason of noise pollution in 73 provinces both at the 2008 and 2010 report, in 78 provinces at the 2012 report. Non-urban highways and country roads are stated as another reason in 25 provinces at the 2008 report, in 23 provinces at the 2010 report, and in 27 provinces at the 2012 report. Railway transportation is also issued as a problem in 26 provinces both at the 2008 and 2010 report and in 24 provinces at the 2012 report. The airport close to the settlements is another reason in 14 provinces at the 2008 report, in 15 provinces at the 2010 report, and in nine provinces at the 2012 report.

In order to avoid the problem of noise pollution, the following measures were taken: more restrictive measures to create a quiet area in 20 provinces, traffic planning and road barrier systems in 17 provinces at the 2008 report. They are 20 and 27 at the 2010 report and 53 and 14 at the 2012 report.

Implementation of actions plans, which are prepared depending on the noise maps as a planning decision, is taken as a measure in five provinces at the 2008 report. Those provinces are Corum, Erzurum, Gaziantep, Istanbul, and Trabzon. That measurement is stated in the eight provinces at the 2010 report and again in five provinces at the 2012 report.

However, at the last report, noise pollution is considered in a very limited manner. Neither reasons, nor measures are mentioned at the last report.

We can see all those information summarised as a table below (see Table 2).

\footnotetext{
7 The Bank of Provinces, "Technical Contract for Reconstruction Plans".

8 The Ministry of Environment and Urbanization. (2008, 2010, 2012). Reports of "Turkey Inventory Assessment Report on Environmental Problems and Priorities". Ankara, Turkey.
} 
Table 2

Number of Provinces in Turkey, According to the Air and Noise Pollution Problem and the Measurement Methods at Each Report

\begin{tabular}{|c|c|c|c|c|c|}
\hline & & 2008 report & 2010 report & 2012 report & 2014 report \\
\hline Reasons of air pollution & $\begin{array}{l}\text { Traffic as a primary } \\
\text { reason }\end{array}$ & 3 provinces & 2 provinces & 4 provinces & 5 provinces \\
\hline \multirow[t]{2}{*}{$\begin{array}{l}\text { Measurement methods of air } \\
\text { pollution }\end{array}$} & $\begin{array}{l}\text { Motor vehicle exhaust } \\
\text { gas measurements }\end{array}$ & 75 provinces & - & $\begin{array}{l}102 \text { settlement } \\
\text { units }\end{array}$ & \multirow[t]{3}{*}{$\begin{array}{l}173 \text { settlement } \\
\text { units }\end{array}$} \\
\hline & Urban transport & 73 provinces & 73 provinces & 78 provinces & \\
\hline \multirow{3}{*}{ Reasons of noise pollution } & $\begin{array}{l}\text { Non-urban highways and } \\
\text { country roads }\end{array}$ & 25 provinces & 23 provinces & 27 provinces & \\
\hline & Railway transportation & 26 provinces & 26 provinces & 24 provinces & \multirow{2}{*}{ Not mentioned } \\
\hline & $\begin{array}{l}\text { The airport close to the } \\
\text { settlements }\end{array}$ & 14 provinces & 15 provinces & 9 provinces & \\
\hline \multirow{2}{*}{$\begin{array}{l}\text { Measurement methods of } \\
\text { noise pollution }\end{array}$} & $\begin{array}{l}\text { More restrictive } \\
\text { measures to create a } \\
\text { quiet area }\end{array}$ & 20 provinces & 20 provinces & 53 provinces & \multirow[t]{2}{*}{ Not mentioned } \\
\hline & $\begin{array}{l}\text { Traffic planning and road } \\
\text { barrier systems }\end{array}$ & 17 provinces & 27 provinces & 14 provinces & \\
\hline
\end{tabular}

When reports are analysed, it is seen that there is a rapid increase in the measurement method on "Motor vehicle exhaust gas measurements". This increase is guessed because of the technic used on numerical system. At the 2008 report, only the provinces are counted. However, at the 2012 and 2014 reports, all the settlement units, such as districts in the province, are taken into account. Urban transportation measures seem to keep the same rate to prevent air pollution for the same provinces. It propably means that, in all those provinces, there are both air pollution and transportaion problems together.

Figure 6 shows us the reasons of noise pollution as a separate figure. Showing the reasons of air pollution in a graph is not found useful as only one reason is stated and that reason is stated in only three or five provinces. As at the 2014 report, reasons of noise pollution are not mentioned, there is no input for that report at this figure.

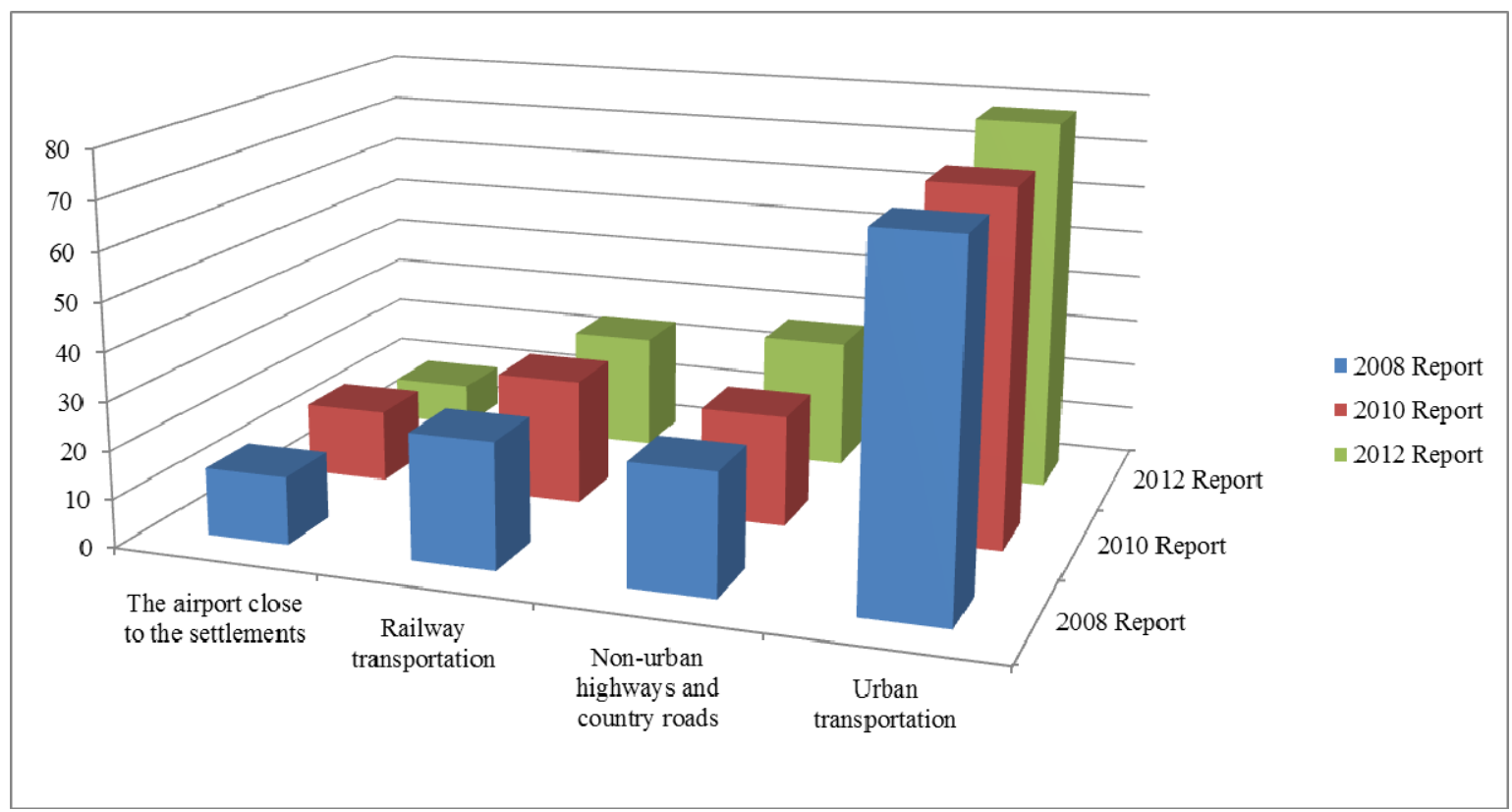

Figure 6. The number of provinces versus the reasons of noise pollution which are stated for each report. 
When we compare both the reasons of air and noise pollution, the issues related with the transportation are seemed to be different from each other according to their effects on environment. This result is produced because the number of provinces is not complete both for air and noise pollution. And this may be because of the reality or the habitants perception, senses, assumptions, knowledge, or awareness of the relationship between air and noise pollution of transportation.

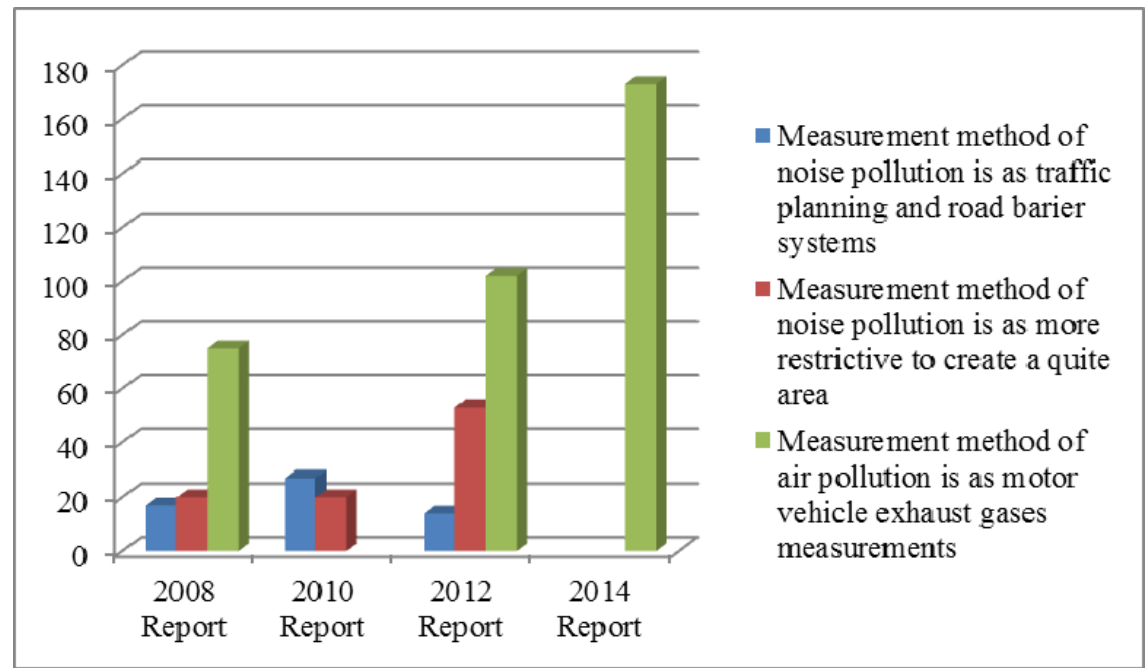

Figure 7. Number of provinces for 2008 and 2010 reports and number of settlement units for 2012 and 2014 reports in which measurement methods both for air and noise pollution are used according to the reports.

Moreover, it is seen that there is no measurement method combatting with noise pollution and motor vehicle exhaust gases measurement method is the only way of struggling with air pollution for transport as the year for 2014 (see Figure 7). That is beacause there is no noise pollution generated by transport anymore or combatting with noise pollution generated by transport is not ignored and if so then this is another case to be considered.

The last graph below (see Figure 8) indicates the number of provinces in which primary problem is as an air or a niose pollution.

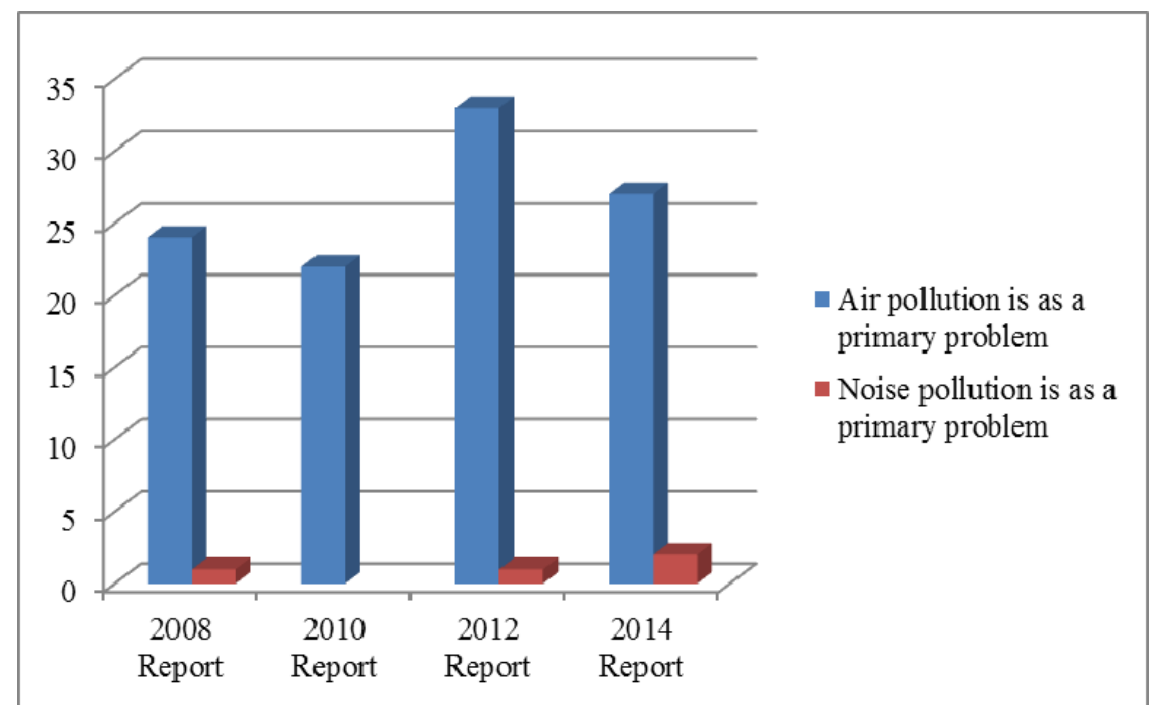

Figure 8. Number of provinces in which air and noise pollution is stated as a primary problem. 
And finally, all graphs give us an idea on the provinces which propose us the measurement methods against both air and noise pollution. Each report consists of two years' period before it is published.

\section{Conclusions and Review}

Even in recent strategy documents, laws, and regulations, energy efficiency in transportation, environmental protection, clean urban transportation in the direction of the choice of transport are mentioned as very important issues, unfortunately, it seems to be just one step closer by such policies.

Existing applications have an impression on local governments in our country that they were unaware of the importance of the subject. Road transport is still kept at the forefront investments in roads and motor vehicles have priority and unfortunately, the traffic is being carried on through damaging the environment in an ineffective and inefficient use of energy.

Of course, the above-mentioned laws, regulations, and strategy documents are to be made quickly and in a very short period of time have a positive effect. However, it should be noted that fast effort and start is required to transfer those regulatory rules to the widespread practice.

Regulation on the Principles and Procedures for Promotion of Energy Efficiency in Transportation can be shown as an example of this fast start. According to the regulation published on June 9, 2008, metropolitan municipalities and municipalities having hundred thousand inhabitants are asked to prepare urban transport master plan. It is required to prepare urban transport plans within three years from the date of publication. This period was ended June 9, 2011.

So far, how many urban transportation master plan is prepared by the municipalities? How many has been implemented? How many municipality has taken action to prepare? How many of them are induced by the central administration in the direction of preparation? The answers to all these questions are needed to be known.

As a result, within the framework of the powers and responsibilities undertaken by local authorities to realize the "green transport":

(1) Establishment of "green" transportation planning, integrated "sustainable" land use and spatial planning should be carried out together within the scope of cooperation between local government and central authorities. Administrative, legal, and technical infrastructure should be established for the realization of the cooperation;

(2) "Clean" transport principles should be adopted into the urban planning process, transportation measures and policies should be evaluated in an "environmentally sensitive" manner, and active participation of engineering, social sciences, and natural sciences experts should be realized within the cooperation of urban and transportation planners;

(3) Within the scope of the use of clean energy, recommendations for the use of the most efficient modes of transport and spatial planning decisions should be guided environmentally sensitively;

(4) The most efficient transport mode decisions and practices should be preferred considering the minimum of adverse effects on the environment and climate;

(5) Mixed-use principles and objectives should be established taking into account public transport along the corridors, pedestrian and bicycle roads, and eco-settlement land-use rules;

(6) Walking and cycling routes should be established for the construction of infrastructure and urban development plan should include these details; 
(7) Purifying individually motor vehicle mobility, pedestrian paths should be supported by environmentally sensitive transportation and urban design, giving importance to the accessibility and usability of space for everyone;

(8) Extension of the platform for the use of vehicles, contruction of speedway, and interchange arrangements must be surrendered, giving priority to the people but not to the vehicle, pedestrian, bicycle, and public transport planning solutions had to be implemented especially in urban centers;

(9) Particularly in the use of existing urban transportation, access should be given primarily to the pedestrian, secondary passenger vehicle. Urban design should be realized taking into account and caring about the traffic calming principles, shared pathway, the electronic road guidance, and road and parking charges;

(10) Parking areas should be reduced evaluating together with the public transportation systems in certain areas of the city, especially in urban center;

(11) In this context, park-and-ride system should be planned and implemented as soon as possible for all the cities, especially in urban centers;

(12) Decisions affecting land use changes and the related transportation trends should be examined and revised in urban plans;

(13) Transport activities, which are an important factor in conservation of the environment, must be considered within the framework of planning, in particular, the upper structure of urban transport and urban traffic network should be managed by the intelligent transportation systems through urban traffic control centers;

(14) In an environmentally sensitive manner, urban transport pricing policies such as "user-pays" principle should be applied at the management of transport infrastructure.

It is expected from local governments that they should be aware of their responsibilities on urban transportation and they should use their power for the use of sophisticated planning and transportation arrangements with a "green" environmentally sound manner in future.

\section{References}

Grazi, F., \& van den Bergh, J. C. J. M. (2008). Spatial organization, transport and climate change: Comparing instruments of spatial planning and policy. Ecological Economics, 67(4), 630-639.

Gust, I., \& Expert Commission on Cities and Climate Change. (2010). Heading for 100\% renewable urban transport. HafenCity University.

Kaplan, H. (1996). Urban transportation planning-1, subject to transportation planning course notes book 7: Traffic composition; city relationship between surface-transport types. Faculty of Engineering, Gazi University, Ankara, Turkey.

Kaplan, H. (2009). An analysis of local government's implementations in terms of eco-friendly transport practices in Ankara. File 11, Local Government, Transport and Water, the Chamber of Architects of Turkey, pp. 55-70.

Kaplan, H. (2011). Urban transport priorities, environmental oriented + human-oriented urban transportation planning and regulations. The Mimaran, number 7, pp. 32-36.

Kaplan, H., \& Kaynak, Z. (2011). Green transportation types and regulations: An analysis from the authorities and responsibilities of local governments. TRANSIST 2011, IV. Transport symposium, pp. 160-174, Istanbul. Retrieved from https://www.researchgate.net/publication/290998437_YESIL_ULASIM_TUR_VE_DUZENLEMELERI_YEREL_YONETI MLERIN_YETKI_VE_SORUMLULUKLARI_YONUNDEN_BIR_IRDELEME

Kaynak, Z. \& Kaplan, H. (2009). An analysis of local governments' responsibilities and powers under the environmental issues of transport. Transport Congress. Published paper, pp. 271-278, Istanbul.

McGlade, J. (2008). Foreword. In Transport at a crossroads. TERM 2008: Indicators tracking transport and environment in the European Union. EEA Report No. 3/2009. Retrieved from http://www.eea.europa.eu/publications/transport-at-a-crossroads

Ministry of Transport. (2005). Transport and communications policy of the century. Retrieved from http://www.ubak. gov.tr/tr/sura/21yuzyil/politka.html 
Ministry of Transport. (2009). Energy eficiency on transportation. Retrieved from http://www.ubak.gov.tr/BLSM_WIY S/.../20110408_092927_204_1_44520.pps

The Ministry of Environment and Urbanization. (2010). Regulation on assessment and management of environmental noise. Retrieved from http://www.resmigazete.gov.tr/eskiler/2010/06/20100604-5.htm

TUBITAK. (2004). The vision 2023 technology foresight project. Retrieved from https://www.tubitak.gov.tr/tubitak_content_ files/vizyon2023/Vizyon2023_Strateji_Belgesi.pdf 